\title{
Ius Filiationis: A defence of Citizenship by Descent
}

\author{
Rainer Bauböck
}

\begin{abstract}
Aristoteles famously defined a citizen as someone 'giving judgment and holding office' in the polity. ${ }^{1}$ Yet, this does not settle the issue since we first need to know who qualifies for holding office. And so he continues: 'For practical purposes a citizen is defined as one of citizen birth on both his father's and his mother's side'. ${ }^{2}$ Times have changed. From the French Revolution, which revived ius sanguinis, until the second half of the 20th century, citizenship was mostly transmitted only from the father to the child. Today, largely as a result of international conventions against the discrimination of women, all democratic states define a citizen as one of citizen birth on either the father's or the mother's side. Yet ius sanguinis remains the dominant rule for acquisition of citizenship worldwide. True, in the Americas the stronger principle is ius soli, the acquisition of citizenship through birth in the territory. But even there those born abroad to citizen parents who were themselves born in the country are recognised as nationals by birth.
\end{abstract}

Given this overwhelming presence of ius sanguinis in nationality law, Costica Dumbrava's call for abandoning it is bold. Some might even say, it is quixotic, but I disagree. It is indeed time to reflect on the future of ius sanguinis and to abandon it as a doctrine linking citizenship to biological descent. Yet there are good practical and normative reasons why the principle of citizenship transmission from parents to children will remain alive and ought to be retained.

Dumbrava runs three main attacks against ius sanguinis: It is tainted by its association with ethno-nationalism; it is inadequate because, in an age of artificial reproduction technologies, same sex marriage and patchwork families, biological descent no longer traces social parenthood; and it is unnecessary since its protective effects can be achieved by other means. I will accept the first and second argument with some modifications but reject the third.

\footnotetext{
1 Aristotle (1962), The Politics. Transl: T.A. Sinclair, revised and commentary:

T. J. Saunders (ed.). London: Penguin, III. i: 169.

2 Ibid, III.ii: 171-2, original emphasis.

(C) The Author(s) 2018

R. Bauböck (ed.), Debating Transformations of National Citizenship,

IMISCOE Research Series,

https://doi.org/10.1007/978-3-319-92719-0_17
} 


\section{Not the only one tainted}

As Dumbrava points out, modern ius sanguinis was seen as a democratic and revolutionary principle in contrast with ius soli that had its origins in the feudal idea that any person (or animal) born on the territory was subject to the ruler of the land. Deriving citizenship from citizen descent rather than territorial birth made it possible to imagine a self-governing people reproducing itself. Dumbrava is of course right that seeing the nation as a community of shared descent across generations made it also easier to justify the exclusion of foreigners as well as the inclusion of co-nationals across the border. Yet this is not a sufficient reason for abandoning ius sanguinis.

First, an ethnonationalist disposition can be overcome while maintaining ius sanguinis if this principle is supplemented with ius soli and residencebased naturalisation. The latter has created an ethnically highly diverse citizenry in continental European immigration countries even in the absence of the additional inclusionary effects of ius soli. The reason for this ethnically inclusive effect of ius sanguinis is simple: If first generation immigrants have access to citizenship and take it up, then ius soli and ius sanguinis does not make much difference: the children of immigrants will be citizens under either rule.

Secondly, a pure ius soli regime is also tainted and not only because of the feudal origins of the principle. Territorial nationalism can be just as nasty as ethnonationalism and may be fanned by thinking of ius soli as the right of the 'sons of the soil'. Even the case of Romania that Dumbrava lists among the problematic ones is ambiguous in this regard. If Romania awards citizenship to the descendants of those born in its lost territories, is this an instance of ius soli or ius sanguinis and an illustration of ethnic or of territorial nationalism? The answer is probably: both. Ius soli and ius sanguinis are therefore not alternatives, but can be combined in benign ways that neutralise the potentially illiberal effects of either principle, as well as malign ways that enhance their nationalist potential for ethnic exclusion and territorial expansion.

Thirdly, pure ius soli also has vicious exclusionary effects for migrants. In most American states, the immigrant generation 1.5 - those who have entered the country as minor children - cannot acquire citizenship before the age of majority. President Obama's Dream Act is an attempt to mitigate some of the worst consequences for the children of irregular immigrants. Even more problematic is the common distinction between nationals and citizens in many Latin 
American states. ${ }^{3}$ Only those born in the territory are considered nationals (they are sometimes also called 'naturals'). They turn into citizens with full voting rights at the age of majority. Immigrants who naturalise become citizens, but not nationals. They remain excluded from many public offices (also the US president still has to be a 'natural born citizen') and they can be deprived of their citizenship status, whereas nationality can often never be lost. In Uruguay even the concept of 'naturalisation' does not exist because those who are not born in the territory can never become 'naturals'. Similar exclusionary effects of ius soli traditions apply to those born abroad to citizen parents. They often do not acquire citizenship unless they are registered in time by their parents and they may lose it unless they 'return' before the age of majority.

If both ius sanguinis and ius soli are tainted in these ways, should we consider an even more radical alternative of abandoning citizenship by birth altogether? Why not replace it with ius domicilii so that citizenship is acquired automatically with taking up residence and lost with outmigration? Or should we maybe replace it with ius pecuniae, ${ }^{4}$ i.e. a global market for citizenships in which individuals can bid for membership status anywhere and states can set the admission price? Neither of these alternatives is morally attractive and something important is lost when we give up birthright citizenship.

\section{Why not ius filiationis?}

Dumbrava's second argument is that developments in reproduction technologies and in the social and legal recognition of new family patterns make ius sanguinis increasingly unworkable and obsolete.

This problem is not entirely new and a solution is already available. International law has long abandoned the idea that children should acquire only one citizenship at birth. Since they can inherit two different citizenships from the mother's and the father's side (maybe in addition to a third one acquired iure soli), why should they not receive the citizenship of both an

Acosta D, (2016), 'Regional Report on Citizenship: The South American and Mexican Cases', EUDO Citizenship Observatory Comparative Reports 2016/01, Florence: European University Institute, available at http:/cadmus. eui.eu//handle/1814/43325

4 Stern, J. (2011), 'Ius Pecuniae - Staatsbürgerschaft zwischen ausreichendem Lebensunterhalt, Mindestsicherung und Menschenwürde', Migration und Integration - wissenschaftiche Perspektiven aus Österreich, Jahrbuch 1/2011, Dahlvik/Fassmann/Sievers (eds.). See also Part I of this volume; Dzankic, J. (2015), 'Investment-based citizenship and residence programmes in the EU', Robert Schuman Centre for Advanced Studies Working Papers 2015/08, Florence: European University Insitute. 
intended and a surrogate mother or an intended father and a sperm donor? Asking the question makes it already clear that the problem is not the multiplicity of citizenships per se, but the mismatch between biologically determined citizenship and parental care arrangements that would also open the door to abusive claims. The traditional solution that is already available in most nationality laws for cases where the biological parent is not the social parent is transmission of citizenship through adoption. ${ }^{5}$ Why should it not be possible to generalise this model from the marginal case of adoption so that a modified ius sanguinis refers to social rather than biological parenthood (as it already does in several jurisdictions)?

The main issue with such a new ius filiationis might be that determination of citizenship is less automatic than it used to be for children born in wedlock to their biological mother and father. Yet states that are committed to the welfare of children have to figure out anyhow how to determine legal parenthood in the more complex family arrangements of contemporary societies. In order to avoid statelessness it is important that every child obtains at least one citizenship immediately at birth. And in order to make sure that children are not caught between conflicting legal norms and can develop stable relations to their countries of citizenship it is important that their citizenship status does not change automatically when they become part of a new family. If these concerns are taken into account through a combination of ius soli with legally determined initial parenthood, what objections can be raised against recognizing primary caregivers as well as persons with additional custodial rights as legal parents who can transmit their citizenship to the child?

\section{Don't abandon the children!}

Dumbrava's third argument is that ius sanguinis is not necessary because children's rights can be protected through other means. He claims that ius sanguinis renders children vulnerable by making their 'access to citizenship ... dependent on parents' legal status, actions or reproductive choices This is indeed a reason why the children of immigrants need ius soli as an independent right to citizenship in their country of birth. Unfortunately, in the US, their birthright citizenship does not prevent them from being deported together with their undocumented parents, whereas immigrant minors who are EU citizens have a right to stay that protects also their primary caregivers from deportation. ${ }^{6}$

5 See the EUDO CITIZENSHIP Database on Modes of Acquisition of Citizenship in Europe, available at http://eudo-citizenship.eu/admin/?p=dataE UCIT\&application=modesAcquisition.

6 Case C-200/02 Zhu and Chen v Secretary of State for the Home Department, 2004; Case C-34/09 Ruiz Zambrano v Office National de L'emploi, 2011. 
Yet small children are in any case dependent on their parents' migration decisions. This is a an equally strong reason why they also have a claim to share their parents' citizenship, since they risk otherwise to remain stranded in their country of birth or be treated as foreigners in their parents' country of nationality. Dumbrava suggests preventing this by 'conferring full migration rights to children of citizens'. But would migration rights become more secure if they are disconnected from the legal status of citizenship that is the only one obliging states to unconditionally admit them? Alternatively, he suggests to "establish a universal status of (legal) childhood that confers fundamental rights regardless of their or their parents' citizenship or migration status'. This is what the Children's Rights Convention, which is one of the mostly widely signed and ratified human rights documents, aims to do. The question is not only whether states are willing to respect these rights, but whether they can be held responsible for protecting them. For this, children need not only human rights, they also need their parents' citizenship.

\section{Delayed citizenship for all?}

Dumbrava has, however, a much more fundamental objection that targets both ius sanguinis and ius soli: Citizenship as membership in a political community should not depend on "contingent facts of birth (descent or place of birth)'. This is a common critique that always leaves me puzzled. ${ }^{7}$ My very existence depends on these contingent facts. Humans cannot will themselves into being but are thrown into the world without choosing where to be born and to which parents. What is morally arbitrary is not that states use these fundamental features of personal identity to determine membership in political communities, but that in our world citizenship provides individuals with hugely unequal sets of opportunities. This is not an inherent feature of birthright citizenship but of the global economic and political (dis)order. If we want to overcome it, we have to address the causes of global inequality directly instead of attributing them to those rules that make individuals equal in status and rights as citizens of a particular state.

Dumbrava's critique focuses, however, on another birthright puzzle that has bothered republican theorists. Shouldn't membership in a self-governing political community be based on consent? And does it not presuppose cer-

7 For nuanced critiques of birthright citizenship based on this idea see Carens, J. H. (2013), The Ethics of Immigration. Oxford: Oxford University Press; Shachar, A. (2009), The Birthright Lottery. Citizenship and Global Inequality. Cambridge, MA: Harvard University Press. 
tain attitudes and skills that first need to be developed $?^{8}$ We may expect that children who are born and grow up in the state territory or who are raised by citizen parents will eventually want to join the political community and will also acquire the skills required for political participation. Yet these are expectations rather than certainties. Dumbrava suggests therefore that 'we could delay the attribution of citizenship until such attitudes and skills are confirmed'. However, since children also depend on the state for their health and education, he adds that they could at least be granted provisional citizenship. The Latin American distinction between nationality acquired at birth and citizenship acquired at majority seems to approximate this idea.

One reading of Dumbrava's proposal is that this is just a terminological distinction harking back to Aristotle's two definitions of citizenship. If we consider as citizens those who 'give judgments and can hold office', i.e. the members of the demos, then children are indeed only provisional citizens but will automatically become full citizens at the age of majority. The other interpretation draws, however, a line between the two statuses that can only be crossed by demonstrating the right attitude and skills. Instead of naturalising immigrants into a birthright community, this community itself would be denaturalised and reconstituted through a citizenship test imposed on all provisional native citizens. It may seem a form of poetic justice to treat natives like immigrants. Yet there is a big difference between expecting and promoting citizenship attitudes and skills and making them a requirement for access to citizenship rights. The only reason why immigrants can be expected to spend a few years as residents before becoming citizens, which gives them time to develop citizenship skills, and to apply for naturalisation, which demonstrates a civic attitude, is that they are birthright citizens of another state who have grown up there.

\section{Citizenship across generations}

Dumbrava concludes by suggesting that the intergenerational continuity of democratic membership should be achieved through consolidating institutions and educating citizens rather than the legal fictions and biological contingencies of birthright citizenship. One might ask why democracies need intergenerational continuity. The answer leads us back to the original justification for ius sanguinis after the French Revolution. It should not be the rulers who determine who the citizens are, nor the citizens themselves through

8 See Dumbrava, C. (2014), Nationality, Citizenship and Ethno-Cultural Belonging, Preferential Membership Policies in Europe. Houndmills Basingstoke: Palgrave Macmillan, chapter 8, 9. 
some democratic procedure in which they decide whom to admit or reject, nor the mere fact of subjection to the laws due to temporary presence in the territory. All of these rules lead to too much contingency and discontinuity with regard to the composition of the citizenry. Promoting civic attitudes and skills among those who are citizens is important, but it cannot resolve the puzzle who has a claim to be a citizen in the first place. Automatic acquisition of membership at birth and for life sets this question aside. It makes citizenship a part of citizens' personal identities that they are likely to accept. And it allows democracies to tap into resources of solidarity and to promote a sense of responsibility towards the common good and future generations.

In a nutshell, these are my two arguments why a modified version of ius sanguinis should be accepted as necessary for democratic states:

In a world of territorial states that control immigration, ius sanguinis (or ius filiationis) is as indispensible as ius soli for protecting the children of migrants. It provides them with the right to stay and to be admitted in their country of birth as well as their parents' country of origin. No other legal status can secure these rights as well as a birthright to dual nationality.

Deriving citizenship from unchosen and permanent features of personal identity - where and to whom one is born - sets aside the politically divisive membership question for the vast majority of citizens, creates a quasi-natural equality of status among them and signals that membership is linked to responsibilities for the common good and for future generations. No citizenship education programme can fully substitute for these signalling effects of birthright citizenship.

Open Access This chapter is licensed under the terms of the Creative Commons Attribution 4.0 International License (http://creativecommons.org/licenses/by/4.0/), which permits use, sharing, adaptation, distribution and reproduction in any medium or format, as long as you give appropriate credit to the original author(s) and the source, provide a link to the Creative Commons license and indicate if changes were made.

The images or other third party material in this chapter are included in the chapter's Creative Commons license, unless indicated otherwise in a credit line to the material. If material is not included in the chapter's Creative Commons license and your intended use is not permitted by statutory regulation or exceeds the permitted use, you will need to obtain permission directly from the copyright holder. 